\begin{tabular}{|c|c|}
\hline Title & Development of New A nion-Conducting Layered Perovskite Type Oxide Electrolytes \\
\hline Author(s) & W atanabe, Hiroshi; Takahashi, Hiroki; Takeguchi, T atsuy a; Y amanaka, Toshiro; Ueda, W ataru \\
\hline Citation & $\begin{array}{l}\text { ECS T ransactions, 28(8), 147-151 } \\
\text { https://doi.org/10.1149/1.3490693 }\end{array}$ \\
\hline Issue Date & 2010 \\
\hline Doc URL & http:/hdl .handle.net/2115/48160 \\
\hline Rights & $\begin{array}{l}\text { () The Electrochemical Society, Inc. 2010. All rights reserved. Except as provided under U.S. copyright law, this work } \\
\text { may not be reproduced, resold, distributed, or modified without the express permission of The Electrochemical Society } \\
\text { (ECS). The archival version of this work was published in ECS Trans., 28(8), pp.147-151. }\end{array}$ \\
\hline Type & article \\
\hline File Information & ECSt28-8_147-151.pdf \\
\hline
\end{tabular}

Instructions for use 


\title{
Development of new anion-conducting layered perovskite-type oxide electrolytes
}

\author{
Hiroshi Watanabe, Hiroki Takahashi, Tatsuya Takeguchi, Toshiro Yamanaka, and \\ Wataru Ueda
}

Catalysis Research Center, Hokkaido University, Sapporo 001-0021, Japan

Layered perovskite oxide $\mathrm{LaSr}_{3} \mathrm{Fe}_{3} \mathrm{O}_{10}$ (LSFO) was characterized by electrochemical measurements and XRD. The $\mathrm{H}_{2}$ sensing property of the oxide with $15 \mathrm{wt} \% \mathrm{Pd} / \mathrm{LSFO}$ anode catalyst in $\mathrm{H}_{2}$ at room temperature was examined. As for $\mathrm{H}_{2}$ sensing, the potential about $0.9 \mathrm{~V}$ was gained in the presence of $\mathrm{H}_{2}$ without cathode catalyst. Furthermore, the membrane potential for concentration cell of $\mathrm{NaOH}$ with LSFO showed negative value, and the potential with anion exchange membrane (AEM) also showed negative value. These results suggest that LSFO shows $\mathrm{OH}^{-}$conductivity and the possibility of a new type fuel cell by using LSFO as electrolyte.

\section{Introduction}

Thermoelectric materials are becoming increasingly important in the field of energy harvesting and conversion. Thermoelectric devices are generally based on heavily doped semiconductors and can be used for cooling applications of for electricity generation directly from a heat source. When supplied by a temperature differential, thermoelectric semiconductors respond by virtue of the Seebeck effect to produce a voltage that could be used to drive an external load. A broad search has been under way to identify new materials with enhanced thermoelectric properties.

Sodium cobalt oxide, $\mathrm{NaCo}_{2} \mathrm{O}_{4}(\mathrm{NCO})$ has received considerable attention due to its unusual thermal electric properties [1]. NCO pellets with anodes consisting of $15 \mathrm{wt} \%$ $\mathrm{Pd} / \mathrm{NCO}$ showed reasonable potential in oxygen excess atmosphere, we can convert the catalytic combustion heat to electrical energy by usual thermoelectric conversion. However, the potential in hydrogen excess atmosphere showed $0.8 \mathrm{~V}$. This value in hydrogen excess atmosphere could not be explained by thermal electric properties. This phenomenon may come from layered structure. This hypothesis suggests that the possibility of a new type fuel cell by using layered compounds for electrolyte.

$\mathrm{LaSr}_{3} \mathrm{Fe}_{3} \mathrm{O}_{10}$ (LSFO) is $\mathrm{n}=3$ ruddlesden-popper (RP) type perovskite oxide which has the layered structure.

The RP-type oxides exhibiting ion conduction, electronic conduction and catalysis are attractive for use in many electrochemical applications. For example, RP-type oxides are currently used as cathode material for solid oxide fuel cell (SOFC) [2]. Therefore, LSFO is characterized by electrochemical measurements in hydrogen excess atmosphere, and the carrier in LSFO is determined by measuring membrane potential for concentration cell of $\mathrm{NaOH}(\mathrm{pH} 12$ and $\mathrm{pH} 10)$. 


\section{Experimental section}

\section{$\underline{\text { Preparation of single cell }}$}

LSFO samples were prepared by solid state reaction using powders of $\mathrm{La}_{2} \mathrm{O}_{3}$, $\mathrm{SrCO}_{3}$ and $\mathrm{Fe}_{2} \mathrm{O}_{3}$. These precursors were weighted in stoichiometric proportions, and ball milled at $300 \mathrm{rpm}$ for $30 \mathrm{~min}$, followed by pressing in the form of bars. They were calcined in air at $1400^{\circ} \mathrm{C}$ for $3 \mathrm{~h} \mathrm{[3].} \mathrm{The} \mathrm{powder} \mathrm{samples} \mathrm{thus} \mathrm{obtained} \mathrm{were} \mathrm{reground} \mathrm{in}$ an agate mortar. Finally, the powder samples were pressed into pellets and sintered in air at $900^{\circ} \mathrm{C}$ for $10 \mathrm{~h}$. The resulting pellets were cylinder shapes with $5 \mathrm{~mm}$ thick and $10 \mathrm{~mm}$ in diameter. $\mathrm{Pd}$ catalyst $(15 \mathrm{wt} \% \mathrm{Pd} / \mathrm{LSFO})$ was prepared by impregnation method. For preparation of the Pd catalyst, $1.0 \mathrm{~g}$ of LSFO powder and $3.87 \mathrm{~g}$ of $\mathrm{Pd}\left(\mathrm{NO}_{3}\right)_{3}\left(\mathrm{NH}_{3}\right)_{2}$ were added to an evaporating dish. The mixture was kept at $80^{\circ} \mathrm{C}$ on water bath. After evaporating, the mixture was calcined in air at $600^{\circ} \mathrm{C}$ for $2 \mathrm{~h}$, and then ground. The $\mathrm{Pd}$ catalyst was dispersed in ethylene glycol and coated to one side of an electrolyte, then, calcined in air at $400^{\circ} \mathrm{C}$ for $2 \mathrm{~h}$.

This prepared powder was checked by using X-ray powder diffraction patterns collected with a $\mathrm{Cu} \mathrm{K \alpha}$ X-ray source $(40 \mathrm{kV}, 20 \mathrm{~mA})$.

\section{Measurement of electrochemical property}

For the measurement of cell voltage, the cells which were reduced in $\mathrm{H}_{2}$ at $150^{\circ} \mathrm{C}$ for $2 \mathrm{~h}$ were mounted on a teflon specimen support (Figure 1). The measurement was carried out using a three-electrode cell. The Pt wire counter and reference electrode were put on both side pellet. The furnace temperature was set to ambient temperature. The cells were operated in the single-chamber flowing $\mathrm{H}_{2}-\mathrm{O}_{2}-\mathrm{N}_{2}$ mixtures. The total flow rate of the gas mixture was fixed at $100 \mathrm{ml} \mathrm{min}^{-1}\left(\mathrm{H}_{2} / \mathrm{O}_{2} / \mathrm{N}_{2}=37.1 / 3.2 / 59.7\right)$. The changes in the potential were measured for response as a function of time on stream with/without $\mathrm{H}_{2}$ concentration. The flow rate of $\mathrm{H}_{2}$ was switched from $37.1 \mathrm{ml} \mathrm{min}^{-1}$ to $0 \mathrm{ml} \mathrm{min}^{-1}$ and back to $37.1 \mathrm{ml} \mathrm{min}^{-1}$.

We determined the charge carrier in $\mathrm{LaSr}_{3} \mathrm{Fe}_{3} \mathrm{O}_{10}$ by measuring membrane potential for concentration cell of $\mathrm{NaOH}(\mathrm{pH} 12$ and $\mathrm{pH} 10)$. By comparison, we measured the membrane potential of AEM as an anion conducting membrane and Nafion as a proton conducting membrane.

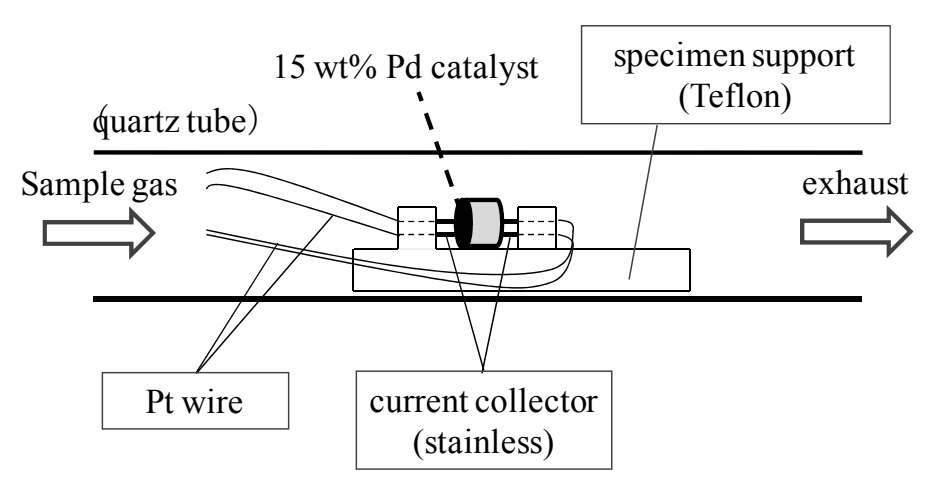

Figure 1. Schematic illustration of the apparatus. 


\section{Results and Discussion}

Figure 2 shows an XRD pattern of LSFO powder. The XRD shows that the product is perovskite oxide LSFO with a tetragonal structure (I4 / $\mathrm{mmm}$ space group), the diffraction date are in good agreement with JCPDS card of $\mathrm{LaS}_{3} \mathrm{Fe}_{3} \mathrm{O}_{9.9}$ (JCPDS card no.01-081-1234). The peaks near $32^{\circ}$ is attributed to [110] and a characteristic peak of $\mathrm{n}=3$ RP-type perovskite.

A plot of the potential at room temperature as a function of time and stream with/ without $\mathrm{H}_{2}$ is shown in Figure 3. The changes in the potential showed a quick response for the presence of $\mathrm{H}_{2}$ at $25^{\circ} \mathrm{C}$. The value of the voltage increased from $0 \mathrm{~V}$ to $0.9 \mathrm{~V}$ within about $3 \mathrm{~min}$ after flowing the $\mathrm{H}_{2}$, and decreased from $0.9 \mathrm{~V}$ to $0 \mathrm{~V}$ within about 3 min after stopping the supply of $\mathrm{H}_{2}$. Furthermore, the cell voltage reached about $0.9 \mathrm{~V}$ without cathode catalyst in the presence of $\mathrm{H}_{2}$. The performance did not change after a number of times this cycle. The results suggested that the Pd/LSFO anode and LSFO cathode were selectively active for hydrogen reduction reaction and oxygen reduction reaction, respectively, since cathode was inert for activation of hydrogen. Oxygen reduction reaction proceed on oxide such as LSFO, since electro-kinetics of oxygen reduction reaction in an alkaline medium is much faster than that in an acidic medium as shown in the following equations [4]:

$$
\begin{array}{llll}
\text { Anode (Pd/LSFO) } & : & \mathrm{H}_{2}+2 \mathrm{OH}^{-} \rightarrow 2 \mathrm{H}_{2} \mathrm{O}+2 \mathrm{e}^{-} & E_{0}=-0.83 \mathrm{~V} \\
\text { Cathode (LSFO) } & : & 1 / 2 \mathrm{O}_{2}+\mathrm{H}_{2} \mathrm{O}+2 \mathrm{e}^{-} \rightarrow 2 \mathrm{OH}^{-} & E_{0}=0.40 \mathrm{~V}
\end{array}
$$

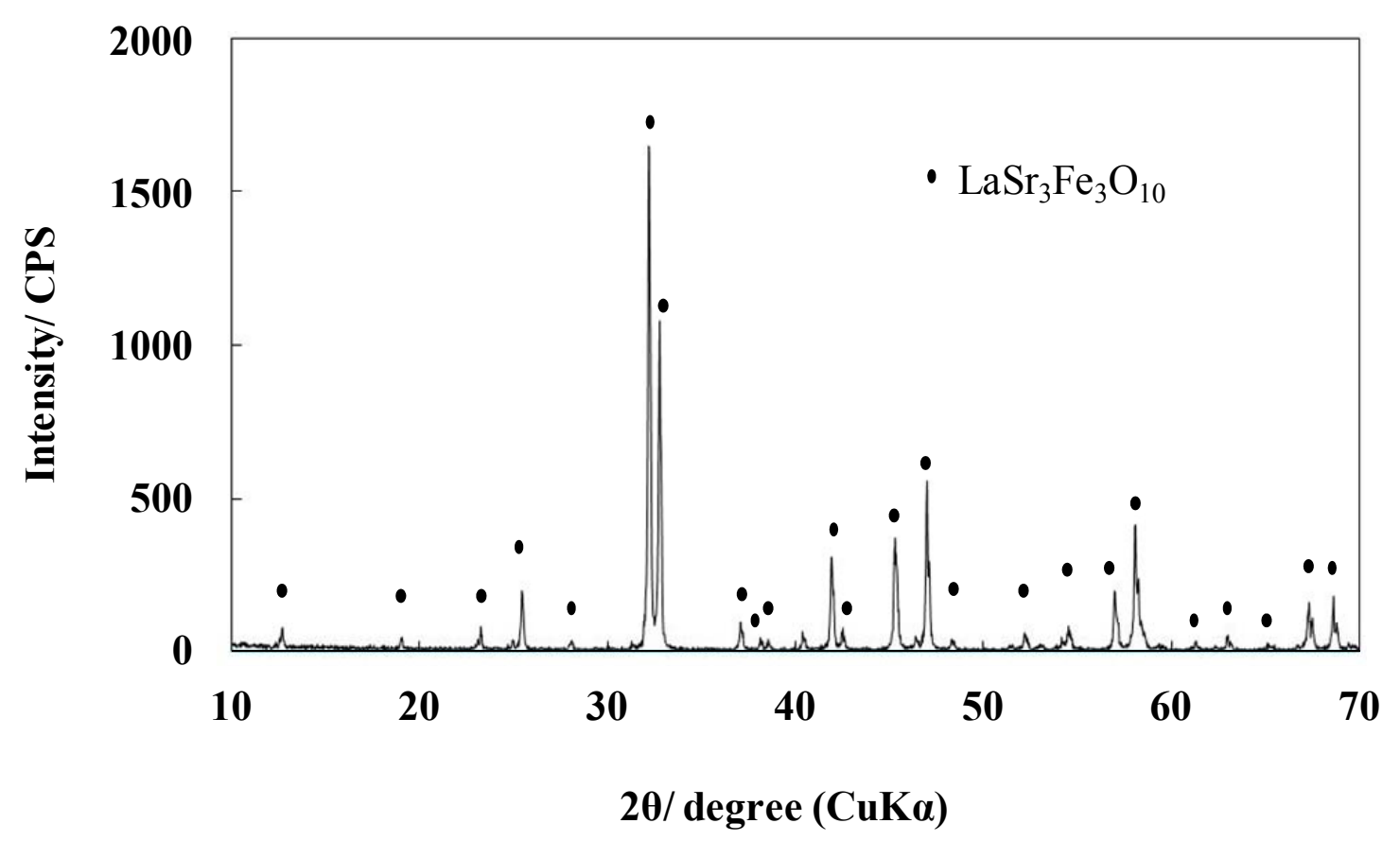

Figure 2. XRD pattern of LSFO powder.

We measured membrane potential for concentration cell of $\mathrm{NaOH}$ to determine the charge carrier. When $\mathrm{KOH}$ solution is used, same results were obtained. The membrane potential of AEM, Nafion, and $\mathrm{LaSr}_{3} \mathrm{Fe}_{3} \mathrm{O}_{10}$ are shown in TABLE I. Nafion was pretreated with $\mathrm{NaOH}$ solution. When electrolyte shows anion conductivity, the membrane potential is $-118 \mathrm{mV}$ from equilibrium potential of Nernst's equation. On the 
other hand, when electrolyte shows only cation conductivity, the membrane potential is $+118 \mathrm{mV}$. For AEM and Nafion, the membrane potential values were negative and positive, respectively. However, both AEM and Nafion were not in agreement with the theoretical value $(-118,+118 \mathrm{mV})$. The results suggest that AEM and Nafion slightly showed cation and anion conductivity, respectively. The membrane potential of LSFO showed negative value. Therefore, the carrier in LSFO was $\mathrm{OH}^{-}$. However, the membrane potential was not in agreement with the theoretical value and adding $\mathrm{NaNO}_{3}$ into the $\mathrm{pH}$ 12 side with LSFO electrolyte, the membrane potential increased (TABLE II). This increase of the potential suggests that LSFO has some cation conductivity. These results suggest that LSFO has both anion and slightly cation conductivities. The main carrier of LSFO was $\mathrm{OH}^{-}$because of showing negative value of the membrane potential adding $\mathrm{NaNO}_{3}$. This $\mathrm{OH}^{-}$can be attributed to the intercalation of water, since the oxygendeficient $\mathrm{n}=3$ Ruddlesden-Popper (RP) type oxides react with water at room temperature [5]. In fact, a peak at $2 \theta=4.9^{\circ}, 9.8^{\circ}$ of the XRD pattern (Figure $4 \mathrm{a}$ ) of the LSFO powder after fuel cell test shows that a new phase contains $\mathrm{H}_{2} \mathrm{O}$ molecules and $\mathrm{OH}$ groups. Therefore, LSFO will be able to be used for a new anion-conducting fuel cell.

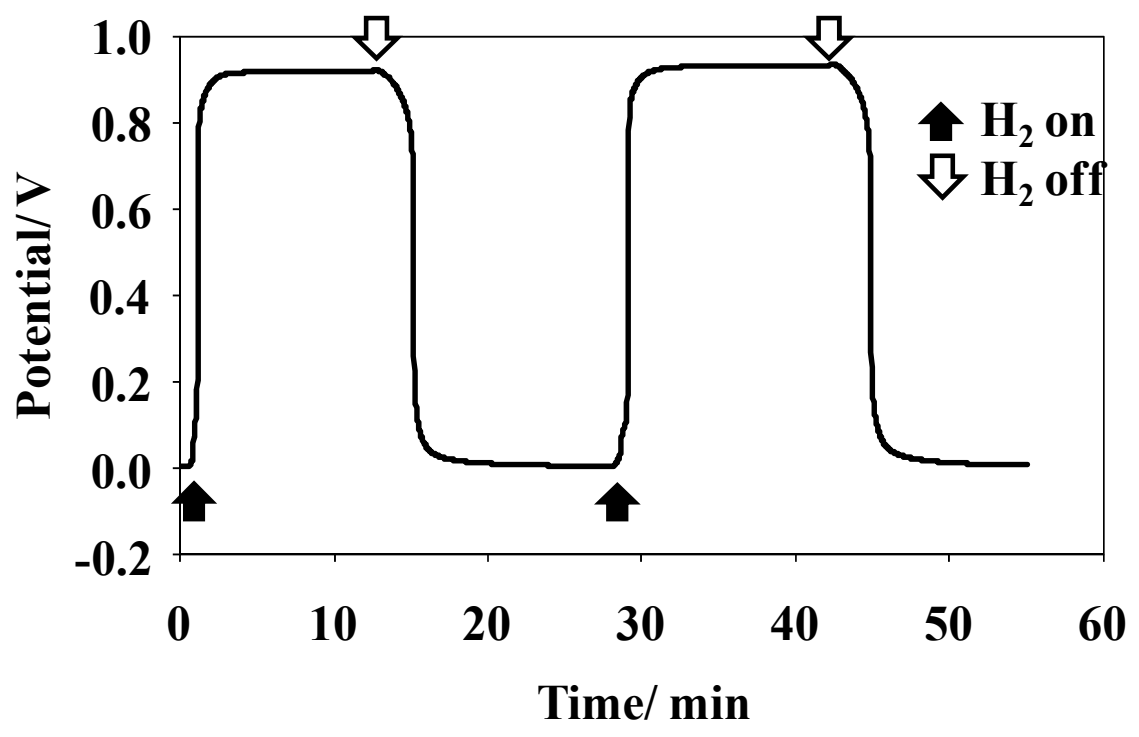

Figure 3. The changes in the potential of the cell consisting of LSFO at room temperature as a function of time and stream with/without $\mathrm{H}_{2}$ concentration in the mixture gas $\left(\mathrm{H}_{2} / \mathrm{O}_{2} /\right.$ $\mathrm{N}_{2}=37.1 / 3.2 / 59.7 \mathrm{ml} \mathrm{min}^{-1}$ )

TABLE I. Membrane potential using three kinds of electrolyte.

\begin{tabular}{cc}
\hline Electrolyte & Membrane potential/ $\mathbf{~ W V}$ \\
\hline LSFO & -60.2 \\
Nafion & 89 \\
AEM & -101 \\
\hline
\end{tabular}

TABLE II. Dependence of potential on $\mathrm{Na}^{+}$concentration with LSFO electrolyte.

\begin{tabular}{cc}
\hline Solution & Membrane potential/ mV \\
\hline $\mathrm{NaOH}(\mathrm{pH} 10)$ and $\mathrm{NaOH}(\mathrm{pH} 12)$ & -60.2 \\
$\mathrm{NaOH}(\mathrm{pH} 10)$ and $\mathrm{NaOH}(\mathrm{pH} 12)+\mathrm{NaNO}_{3}$ & -29.6 \\
\hline
\end{tabular}




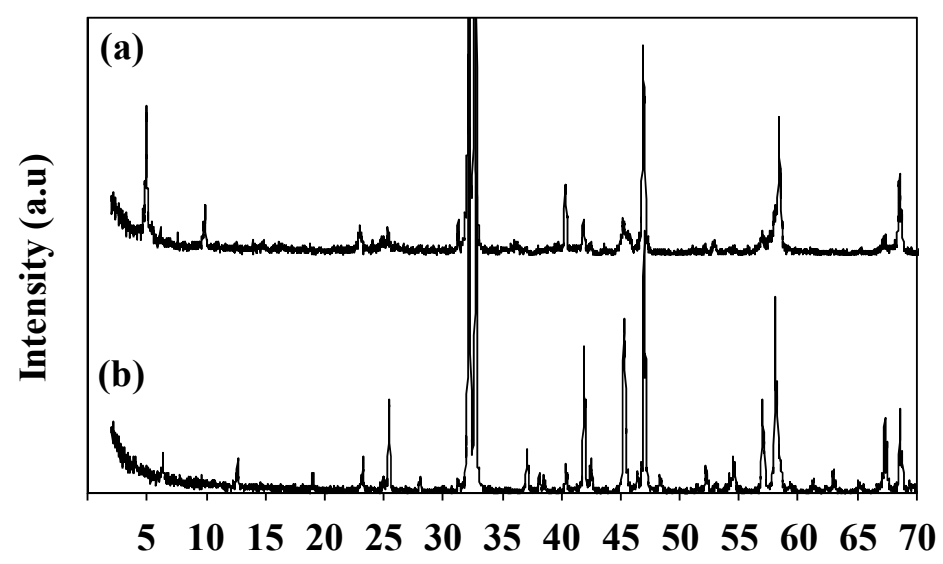

Figure 4. XRD patterns of (a) the LSFO powder after fuel cell test, (b) the as-prepared LSFO.

\section{Conclusions}

$\mathrm{LaSr}_{3} \mathrm{Fe}_{3} \mathrm{O}_{10}$ electrolyte showed very high voltage without cathode catalyst in the presence of $\mathrm{H}_{2}$. The results revealed characteristic property of $\mathrm{AFC}$, and the carrier of LSFO was determined as $\mathrm{OH}^{-}$by the membrane potential for concentration cell of $\mathrm{NaOH}$. These results suggest that the possibility of a new type fuel cell by using LSFO as electrolyte.

\section{Acknowledgments}

This study was partly supported by New Energy and Industrial Technology Development Organization (NEDO) of Japan.

\section{References}

1. I. Terasaki, Y. Sasago, and K. Uchinokura, Phys. Rev., B 56, R12685 (1997).

2. K. T. Lee, D. M. Bierschenk, and A. Manthiram, J. Electrochem. Soc., 153, A1225 (2006).

3. J. Y. Lee, J. S. Swinnea, H. Steinfink, W. M. Reiff, S. Pei, and J. D. Jorgensen, J. Solid State Chem., 103, 1 (1993).

4. J. S. Park, S. H. Park, S. D. Yim, Y. G. Yoon, W. Y. Lee, C. S. Kim, J. Power Sources, 178, 620 (2008).

5. D. Pelloquin, J. Hadermann, M. Giot, V. Caignaert, C. Michel, M. Hervieu, and B. Raveau, Chem. Mater. 16, 1715 (2004) 